\title{
The Top Ten Developments in Studies on Chinese Humanities in 2019-2O2O
}

Chinese humanities scholarship has been robust in recent years and is now going through profound changes. To keep readers abreast of these new developments and trends and to promote humanities scholarship and public awareness, since 2015, the Journal of Literature, History, and Philosophy [Wen shi zhe 文史哲] and Chinese Reading Weekly [Zhonghua dushu bao 中華讀 書報] have jointly chosen the annual “Top Ten Developments in Studies on Chinese Humanities" The selection of 2019 was delayed because of covid-19, so this year's selection covers both 2019 and $202 \mathrm{O}$.

\section{Exploration of the Seeds of National Culture and Justification of the Uniqueness of Chinese Civilization Became a Timely Project}

The disciplines of history and archaeology have stepped outside the "ivory tower" and received wide attention in the past two years. The archaeological excavation of early remains of Chinese civilization and the historical inquiry into the origin of the ancient Chinese state have not only become a hot topic of academic research but also the focus of attention by all walks of life in China. The continuity and uniqueness of Chinese civilization, as well as the historical necessity of the "Chinese path," have become the focus of many studies.

"Without the five thousand years of Chinese civilization, the flourishing path would not exist today." The revival of historical and archaeological studies echoes the era's need to seek answers in the past. Tracing five thousand years of Chinese history, academic endeavors in the humanities, especially history and archeology, will explore the seeds of national culture, reveal the origin and development of Chinese civilization, and justify the prosperity and longevity of Chinese cultural traditions. It is not only an academic task but also a cultural mission to enable the trajectory of Chinese civilization and the choices on the Chinese path to be adequately understood by the world, which will open up a new chapter in the study of ancient history. 


\section{Representative Publications}

Chen Chun 陳淳. "Discussing the Reconstruction of Ancient History from the Perspective of the Development of Archaeological Theory and Methods 從考古學 理論方法進展談古史重建." Historical Research 歷史研究, no. 6 (2018).

Chen Qitai 陳其泰. “The Disciplinary Construction of Ancient Chinese History in the New Era 新時代中國古代史學科建設問題.” Historical Research 歷史研究, no. 1 (2019).

Huang Xingtao 黃興濤. “The Mission of Historical Study in Contemporary China 當代 中國歷史學的時代使命.” Historical Research 歷史研究, no. 1 (2019).

Liu Qingzhu 劉慶柱. “An Archaeological Interpretation of the Continuity of Chinese Civilization over Five Thousand Years 中華文明五千年不斷裂特點的考古學㘓釋.” Social Sciences in China 中國社會科學, no. 2 (2019).

Wang Wei 王巍. “Archeological Evidence of the 5,00o-Year-Old Chinese Civilization 中 華 5000 多年文明的考古實證.” Seeking Facts 求是, no. 2 (2020).

Wang Wei 王巍. “Developing Archaeology and Serving the New Era 發展考古學 服務 新時代.” Historical Research 歷史研究, no. 1 (2019).

Yuan Jing 袁靖 et al. “The Rise and Fall of the Liangzhu Society from the Perspective of a Subsistence Economy 良渚文化的生業經濟與社會興衰.” Archaeology 考古, no. 2 (2020).

Zhang Xiong 張雄. “The Positive Nature of History: Exploring the Cultural Seeds of the Proposed 'Chinese Approach’ 歷史的積極性質 - ‘中國方案’ 出場的文化基因 探析.” Social Sciences in China 中國社會科學, no. 1 (2019).

Zhao Haitao 趙海濤 and Xu Hong 許宏 et al. “Retrospect and Prospect on the Sixtieth Anniversary of Uncovering the Erlitou Relic Site二里頭遺址發現 6o 年的回顧、反 思與展望." Cultural Relics of Central China 中原文物, no. 4 (2019).

\section{Engels's Unique Contributions in "Playing Second Fiddle" Was Newly Interpreted on the Bicentennial of His Birth}

November 28, 2020 was the bicentennial of the birth of the great thinker [Friedrich] Engels, and research on his thinking was the focus. In response to the tendency of Western Marxism to downgrade Engels's thinking, research in China appreciates his uniquely important role in the creation, development, and dissemination of Marxism. Engels not only provided Marx with the basics of scientific exploration but also played "second fiddle" and made irreplaceably original contributions to the establishment, defense, and development of Marxism. 
Engels proposed that the application of Marxism worldwide be based on an understanding of specific conditions of each country, which provided methodological guidance for the historical construction of Chinese Marxism. The thesis that "a socialist society will continually evolve" profoundly enlightens socialist thinking and reforms practice with Chinese characteristics. Engels's reminders that "We should not revel in the victory over the natural world" and that human nature as well as human conflict must be "reconciled" also provide insights for contemporary society as it faces the crises and challenges brought about by modernity.

\section{Representative Publications}

Feng Jingyuan 馮景源. “Inheriting Marx: Engels's Theoretical Contributions in His Later Years 繼承馬克思: 恩格斯晚年的理論貢獻." Southeast Academic Research 東 南學術, no. 4 (2020).

Gong Jingcai 宮敬才. “The Theory of Engels's Dialectical Materialism: A Philosophical System of Its Own 恩格斯讋證唯物主義哲學體系論綱.” Modern Philosophy 現代哲 學, no.1 (2020).

Gu Hailiang 顧海良. “Two 'Great Discoveries' and the Essence of Marxism: Commemorating the Bicentennial of Engels's Birth 兩個'偉大發現'與馬克思主義思 想精粹 - 紀念恩格斯誕辰 200 周年." Studies on Marxist Theory 馬克思主義理論學 科研究, no. 5 (2020).

Hao Lixin 郝立新. “Engels and the Integrity of Marxist Theory 恩格斯與馬克思主義理 論的整體性.” Marxism \& Reality 馬克思主義與現實, no. 6 (2020).

Hou Yanshe 侯衍社. “A Study of Engels's Later Historical Materialist Methodology 恩格 斯晚年唯物史觀方法論思想研究." Philosophical Research 哲學研究, no. 10 (2020).

Li Yinghong 李映紅 and Zhao Di 趙笛. “The Value of Nature in Engels's Ecological Holism 恩格斯生態整體主義自然價值觀探析.” Journal of Nanjing University 南京大 學學報, no. 6 (2020).

Nie Jinfang 聶錦芳. “Engels's Critique of Capital and Its Characteristics 恩格斯的資本 批判及其當代價值." Philosophical Research 哲學研究, no. 11 (2020).

School of Marxism at Peking University 北京大學馬克思主義學院 and the School of Marxism at Sichuan University 四川大學馬克思主義組, ed. The Past and Present of Engels's Thinking: Commemorating the Bicentennial of Engels's Birth 恩格斯思想的 歷史與現實: 紀念恩格斯誕辰 200 周年. Chengdu: Sichuan University Press, 2020.

Tong Jian'an 童建安 and He Zhonghua 何中華. “Differences between Marx and Engels on the Critique of the Feuerbach's Philosophy: Comparing The Outline of Feuerbach with Ludwig Feuerbach and The End of Germany Classical Philosophy 馬克思恩格 
斯在清算費爾巴哈哲學上的差異 - 以〈提綱〉和〈終結〉為比較物件.” Journal of Shandong Youth University of Political Science 山東青年政治學院學報, no. 5 (2019). Wang Haifeng 王海鋒. “Engels in His Later Years and the 'Systematization' of Marxist Philosophy: Investigation of Academic History Based on Historical Materialism 晚年恩格斯與馬克思哲學的體系化' - 基於唯物史觀的學術史考察.” Journal of Huazhong University of Science and Technology 華中科技大學學報, no. 3 (2020).

Wang Xudong 王旭東. “Textual Research on the Editorial Principle in Engels's Editing of Das Kapital, Vol. 2 恩格斯編輯〈資本論〉第 2 冊的編輯原則考證." Studies on Marxism 馬克思主義研究, no. 1 (2020).

Yu Bin 余斌. "Second Fiddle: Genius and Contribution: Commemorating the Bicentennial of Engels's Birth 第二小提琴手: 天才與貢獻 - 紀念恩格斯誕辰 200 周年.” Observation and Consideration 觀察與思考, no. 5 (2020).

Zang Fengyu 藏峰宇. “Engels's Stipulation of 'Justice' and Its Practical Principles in His Later Years 晚年恩格斯對“正義”的規定及其實踐原則.” Philosophical Research 哲學 研究, no. 12 (2020).

Zhang Guangming 張光明. “Late Engels:Thought, Era, and Posthumous History 恩格斯 晚年: 思想、時代及身後歷史.” Journal of the Pudong Chinese Executive Leadership Academy 中國浦東幹部學院學報, no. 4 (2020).

Zhang Leisheng 張雷聲. "On Friedrich Engels's Theoretical Contributions to Karl Marx's Das Kapital 恩格斯對馬克思〈資本論〉的理論貢獻.” Journal of Peking University 北京大學學報, no. 3 (2020).

\section{The Relationship between the Ancient and the Modern as Well as between China and the West Were Rebalanced in Commemoration of the Centennial of the May Fourth Movement}

All three major ideological trends that surged in China during the twentieth century - a Marxist insurrection, total Westernization, and a return to tradition - are directly related to the May Fourth movement (1919). Evaluation of this movement has always elicited divergent opinions and even conflicts. Did an overly radical anti-traditional path in the May Fourth movement cause a crisis of Chinese consciousness, or did the remains of deeply entrenched traditions make the road to China's modernization bumpy? The root of the above-mentioned differences lies in whether the observer's perspective is based on "the difference between China and the West" or "the transition from antiquity to modernity."

In 2019, the centennial of the May Fourth movement was marked with widespread commemorations. In addition to interpreting the May Fourth movement from various perspectives, academics have observed that the US-China trade 
dispute continued to intensify in the twenty-first century, that the humanities are increasingly "localized" in China, and that reviving China has become a dominant theme. The question of "how to deal with tradition" and "how to deal with the West," raised in the May Fourth era have become ever more acute and fundamental. As the Chinese society and culture struggle to achieve modernity, the historical heritage of the May Fourth movement is inevitably related to current and future ideological directions, even choices in the path for development.

\section{Representative Publications}

Luo Zhitian 羅志田. “Bringing 'All under Heaven' Back in Historical Narratives: Exploring the May Fourth Movement from a New Perspective 把'天下'帶回歷史敘 述：換個視角看五四." Social Science Research 社會科學研究, no. 2 (2019).

Ouyang Zhesheng 歐陽哲生. “Materials, Interpretations, and Meanings: A Review of a Hundred Years of Research on the History of the May Fourth Movement 材料、詮 釋與意義探尋 - 百年五四運動史研究之檢視." Historical Research 歷史研究, no. 2 (2019).

Wang, David Der-wei 王德威. “Without the May Fourth Movement, How Would We Have the Late Qing? 沒有五四, 何來晚清? ” Southern Cultural Forum 南方文壇, no. 1(2019).

Wong, Young-tsu 汪榮祖. “Romanticism or Renaissance? A New Discussion of Hu Shi's Contributions and Shortcomings in the May Fourth Movement 啟蒙還是浪漫? 重評胡適在新文化運動中的功與過." Journal of Literature, History, and Philosophy 文史哲, no. 2 (2019).

Xiang Jiuyu 項久雨. "The May Fourth Movement and the Character and Rule of the Dissemination of Marxism in China 五四運動與馬克思主義在中國傳播的特點及 規律." Studies on Marxism 馬克思主義研究, no. 4 (2019).

Yang Guorong 楊國榮 et al. "Reflection on the May Fourth Movement: Rebalance between China and the West, and Antiquity and Modernity 反思“五四': 中西古今 關係再平衡." Journal of Literature, History and Philosophy 文史哲, nos. 5-6 (2019).

Yang Nianqun 楊念群. “The History of Individualism around the May Fourth Movement and Its Relationship to Socialism and Collectivism 五四前後個人主義興衰史 - 兼 論其與“社會主義, “團體主義”的關係.” Modern Chinese History Studies 近代史研究, no. 2 (2019).

Zhao Dunhua 趙敦華. “A Centennial Review of the May Fourth Movement 百年回首話 五四.” Journal of Peking University 北京大學學報, no. 3 (2019).

Zou Xiaodong 鄒曉東. “Can Confucianism Be Reconciled with 'May Fourth’? 儒學與·五 四'能和解嗎? ”Chinese Reading Weekly 中華讀書報, June 12, 2019, p. 13. 
A Retrospective on the Past Seventy Years of Academic Progress and the Prospects for a Third Paradigm Shift in the Humanities

The history of humanities in twentieth-century China was determined by two paradigm shifts. The first was the shift from academia in the Republic of China [1912-1949] to academia in the People's Republic of China, and the second was the shift from focusing on issues of class to focusing on issues of modernization. The second shift, accompanied by Chinese economic reform, enabled academic research to prosper, and its development in the twenty-first century is based on its accumulation after this shift. Nonetheless, what has also appeared in academia for the purpose of correcting the partial emphasis on politics in the past is a tendency to avoid realism and almost reconstruct an ivory tower. In engaging with the world and learning from the West, some studies became overly Westernized.

On the seventieth anniversary of the founding of the People's Republic of China, the disciplines of literature, history, and philosophy reflected on history and envisioned the future. Only when academia is rooted in the soil of Chinese society, facing and responding to the problems of the times, will there be sustainable development, which will depend on the third shift that humanities research is experiencing: a directional shift from Westernization to Sinicization. The third shift involves the construction of a system of philosophy and social science with Chinese characteristics, making social sciences more Chinese as well as making Confucianism more scientific. This shift will bring new opportunities and challenges for the humanities in China.

\section{Representative Publications}

Bu Xianqun 卜憲群. “The Road of the Development of Historiography since the Founding of New China 新中國七十年的史學發展道路.” Journal of Chinese Historical Studies 中國史研究, no. 3 (2019).

Chen Xiaobin 陳曉斌. “The Awareness of Questioning and Paradigm Shifts: Seventy Years of Marxism Studies 馬克思主義哲學研究 70 年的問題意識及其範式轉換.” Journal of Sichuan University 四川大學學報, no. 4 (2019).

Cheng Lin 程霖, Zhang Shen 張申, and Chen Xudong 陳旭東. “Explorations of Chinese Economics: A Historical Investigation 中國經濟學的探索: 一個歷史考察.”Economic Research 經濟研究, no. 9 (2020).

Fang Weibao 方維保. "Seventy Years of the Contemporary Novel: Shifts in the Era and Changes in Aesthetics 當代長篇小說七十年：時代潮涌與審美嬗變." Commentaries on Literature and Art 文藝論壇, no. 2 (2020). 
Huang Daoxuan 黃道炫. “The First Experience of Conquering Mt. Guanshan: Studies on the Past Seventy Years of Chinese Communist Revolutionary History 關山初 度: 七十年來的中共革命史研究.” C C P History Studies 中共黨史研究, no. 1 (2020).

Liu Yuejin 劉躍進. “The Construction of a Disciplinary System in the Past Seventy Years of Chinese Literary Studies 70 年來中國文學研究的學術體系建構." Literary Review 文學評論, no. 5 (2019).

Wang Liming 王利明. “Seventy Years of Studies on Chinese Civil Law: Retrospect and Prospect 中國民法學七十年: 回顧與展望.” Tribune on Political Science and Law 政 法論壇, no. 1 (2020).

Wang Lixin 王立新. “Seventy Years of Chinese Studies on American History 七十年 來中國的美國史研究." Chinese Journal of American Studies 美國研究, no. 4 (2020).

Wang Xuedian 王學典. "Great Shifts in Academia: A Retrospective on Forty Years of Humanities and Social Sciences 學術上的巨大轉型: 人文社會科學 40 年回顧.” Chinese Reading Weekly 中華讀書報, January 2, 2019, p. 5 .

Wang Xuedian 王學典. “The Development of Chinese Discourse: Localization of Western Social Sciences and Social Scientification of Confucianism 中國話語 形成之路：西方社會科學的本土化和儒家思想的社會科學化." Journal of Jinan University 濟南大學學報, no. 6 (2019).

Wang Zhongjiang 王中江 and Yao Yurui 姚裕瑞. “An Overview of the Past Seventy Years of Research on Chinese Philosophy 曲折、轉變與新進展 - 中國哲學 70 年研 究歷程回顧." Social Science Front 社會科學戰線, no. 8 (2019).

Zhongguo shehui kexue yuan 中國社會科學院. Book Series in Celebration of the Seventieth Anniversary of the People's Republic of China 中國社會科學院慶祝中華人 民共和國成立 70 周年書系. Beijing: China Social Sciences Press, 2019.

Zhou Xinglu 周興陸. “Two Academic Paradigm Shifts: Retrospect and Reflection on Seventy Years of Studies on Ancient Literature in New China 學術範式的兩次變 革 - 新中國 70 年古代文學研究回顧與反思." Study \& Exploration 學習與探索, no. 8 (2019).

\section{The Prospects for Human Civilization Raised Academic Concerns over the Consensus on Western Social Values}

In the history of human civilization, 2020 might be a landmark. Marked by a controversial US presidential election and a growing trend of "America opposing America," Western civilization seems to have reached a moment when a decision must be made. Based on observations in the humanities, though the perceptions of "Trumpism" and "Bidenism" vary, whether the former is regarded as right-wing populism or the latter is regarded as left-wing 
radicalism, the sharp opposition and rupture between the two ideologically have been thoroughly exposed, which has created a great division in the social consensus of American society, with shock waves emanating and echoing in different corners of the world.

Because of the status of the United States in the Western world as a "beacon," the collapse of values reflected in the fifty-ninth US presidential election will inevitably cast a shadow on the prospects for Western civilization. Through this unprecedentedly extensive dispute over core values, where Western civilization and even human civilization are headed has become an urgent and profound issue that the humanities can no longer avoid.

\section{Representative Publications}

Cong Riyun 叢日雲. “Populism or Conservatism: On Western Intellectual Misunderstanding of the Trump Phenomenon 民粹主義還是保守主義 - 論西方知 識界解釋特朗普現象的誤區." Exploration and Free Views 探索與爭鳴, no. 1 (2020).

Huang Yusheng 黃裕生. “The Continuity and Discontinuity of Civilization 如何理解文 明的延續與中斷：從一個說法談起.” Chinese Culture 中國文化, no. 1 (2020).

Liu Qing 劉擎. “Annual Review of Western Thinking in 2020 活久未見之年, 西方人 到底在想什麼? 2020 西方思想年度述評” Beijing Cultural Review (WeChat Official Account) 文化縱橫微信公眾號, March 23, 2021.

Pang Jinyou 龐金友. “The Unavoidable Split: Value Conflicts and Conceptual Differences behind the US Election 無法擺脫的撕裂: 美國大選背後的價值衝突 與觀念歧異." Contemporary American Review 當代美國評論, no. 4 (2020).

Ren Jiantao 任劍濤. "Reconstructing the State: The Theoretical Presumption of Trump's Political Ideas 重構國家: 特朗普理念的政治理論推定." Contemporary American Review 當代美國評論, no. 4 (2020).

Wang Jianxun 王建勳. "Culture War, Conservatism, and the Future of Western Civilization 文化戰爭、保守主義與西方文明的未來.” Contemporary American Review 當代美國評論, no. 3 (2019).

Wang Xi 王希. “The 'American Experiment' and the 'American Crisis': The Presidential Election System behind the ‘Trump Phenomenon’ “美國實驗”與“美國危機” - 特朗普 現象背後的總統選舉制度." Beijing Cultural Review 文化䍃横, no. 6 (2020).

Zou Hongjin 鄒虹瑾 and Xie Tao 謝轁. “The Fight over Ideology in the US Presidential Election: The Case of Partisan Realignment in California 美國總統選舉中的價值觀 之爭：以加利福尼亞州的嬗變為例." Contemporary American Review 當代美國評 論, no. 4 (2020). 


\section{The Nishan World Center for Confucian Studies Was Inaugurated in the Birthplace of Confucius with the Return of the Center for Confucian Studies to Mainland China}

Since the eighteenth National Congress of the Chinese Communist Party (2012), the momentum in Confucian studies in China has become stronger. Based on the revival of folk Confucianism over thirty years, Confucianism has been clearly accepted as an important ideological resource in state governance. The inheritance and development of traditional Chinese culture have become national cultural strategies. Contrary to the time when people flocked to study Confucianism overseas in the 1980s and 199os, world-renowned Confucian scholars who were active overseas, such as Tu Weiming, Roger T. Ames, Chung-ying Cheng, Lin Anwu, and Daniel A. Bell, have come to work in mainland China in recent years. This ended a long era in which Confucian studies were conducted in mainland China yet the centers for Confucian studies were overseas. The location of this center attracted much attention.

To facilitate the development of Confucian studies in mainland China, the Nishan World Center for Confucian Studies was officially established by the Ministry of Education and Shandong Province on August 25, 2019. Because the Nishan World Center for Confucian Studies is a physical communication platform for global Confucian studies under the guidance of the top national authority in education, its establishment can be regarded as the most ambitious and iconic measure for reviving traditional Chinese culture since the establishment of China Confucius Foundation, approved by the Central Committee of the Communist Party of China in 1984. It will provide powerful support for the ideal of "making our country take initiatives in the Confucian cultural circles in East Asia, maintaining discourse power in the dissemination and research on Confucianism around the world."

\section{Representative Publications}

Ames, Roger T. 安樂哲. Confucianism and Transformations in the World Cultural Order 儒學與世界文化秩序變革. Jinan: Jinan Press, 2020.

Chen Lai 陳來, ed. The Humanism in the Third Stage of Confucianism: Anthology in Celebration of Tu Weiming's Eightieth Birthday 儒學第三期的人文精神 - 杜維明先 生八十壽慶文集. Beijing: People’s Publishing House, 2019. 
Cheng, Chung-ying 成中英. The Ontology of I Ching 易學本體論. Beijing: Commercial Press, 2020.

Li Zilu 李子路 and Zhang Guodong 張國棟. “The Nishan World Center for Confucian Studies Established 尼山世界儒學中心成立.” Dazhong Daily 大眾日報, August 26, 2019, p. 8.

Lin Anwu 林安梧. Confucianism, Daoism, Buddhism, and Twenty-First-Century Human Civilization 儒道佛三家思想與二十一世紀人類文明. Jinan: Shandong People's Publishing House, 2017 .

Wang Xuedian 王學典. “The World Research Center for Confucianism Returns to Mainland China: The Trends in Confucianism since the Eighteenth National Congress of the Chinese Communist Party 世界儒學研究中心已重返中國大陸 十八大 以來儒學變遷之大勢.” Chinese Reading Weekly 中華讀書報, December 13, 2017, p. 5 . Zhao Qiuli 趙秋麗 and Li Zhichen 李志臣. “Confucianism Setting Off Again from Nishan: On the Founding of the Nishan World Center for Confucian Studies 儒學, 從尼山再出發 - 寫在尼山世界儒學中心成立之際." Guangming Daily 光明日報, August 27, 2019, p. 9.

\section{Pedagogical Reform or Disciplinary System Shift? The Concept of "New Liberal Arts" Sparked Heated Discussion}

The construction of new liberal arts has entered the stage of full implementation with the Declaration on the Construction of New Liberal Arts released in November 2020. But what exactly "new liberal arts" are and what is new about "new liberal arts" are questions that need to be addressed. The majority believes that constructing new liberal arts is about innovating talent training models based on the integration of technology and the humanities, but some observers point out that constructing new liberal arts is about initiating a paradigm shift in the research of liberal arts as well as adjusting the discourse system.

In fact, the concept of new liberal arts collectively refers to the disciplines of literature, history, philosophy, politics, economics, and law. It comprises half the subject territory and should not be compared with "new engineering," "new medicine," or "new agriculture." Positioning the "new liberal arts" matters for the development of Chinese academia in liberal arts. In the context of the increasing localization of the humanities in China, the building of a philosophy and social science system using Chinese experience, materials, data, traditions, and paths is a historical responsibility. 


\section{Representative Publications}

Fan Liming 樊麗明. “New Liberal Arts: The Needs of Era and the Focus of Construction 新文科：時代需求與建設重點.” Chinese University Teaching 中國大學教學, no. 5 (2020).

Fan Liming 㚞麗明. “The Connotation and Development Path for the Construction of New Liberal Arts 新文科建設的內涵與發展路徑.” Chinese Higher Education Research 中國高教研究, no. 10 (2019).

Liu Shuguang 劉曙光. “New Liberal Arts: Thinking Mode and Academic Innovation 新 文科與思維方式、學術創新. Journal of Shanghai Jiaotong University 上海交通大學 學報, no. 2 (2020).

Ning Qi 寧琦. “Social Demand and Core Tasks in the Construction of New Liberal Arts 社會需求與新文科建設的核心任務.” Journal of Shanghai Jiaotong University 上海 交通大學學報, no. 2 (2020).

Wang Mingyu 王銘玉. “New Liberal Arts: A Revolution in Liberal Arts Education 新文 科: 一場文科教育的革命.” Journal of Shanghai Jiaotong University 上海交通大學 學報, no. 1 (2020).

Wang Xuedian 王學典. “What Are 'New Liberal Arts'? 何謂‘新文科’?” Chinese Reading Weekly 中華讀書報, June 3, 2020, p. 5 .

Wu Yan 吳岩. “From Passive to Active: The Turn of Constructing New Liberal Arts “守 城”到“攻城”: 新文科建設的時代轉向.” Exploration and Free Views 探索與爭鳴, no. $1(2 \mathrm{O} 2 \mathrm{O})$.

Zhang Baoming 張寶明. “Reflections on New Liberal Arts: Joys and Fears 新文科之思: “一則以喜, 一則以懼.” Chinese Reading Weekly 中華讀書報, August 6, 2020, p. 5.

\section{As the Concept of an "Involution" Resonated in Academia, a Low-Level Repetitive Cycle in Academic Research Remains to Be Broken}

In the second half of 2020 , the sociological term "involution" unexpectedly became popular online. It became a term widely used by the general public, especially favored by young people to describe their plight in daily life. The concept of involution was first proposed by the American anthropologist Clifford Geertz. Since then, historians such as Prasenjit Duara and Philip C. C. Huang have applied this concept to the study of economic history in the Ming [13681644] and Qing [1616-1911] dynasties to refer to "growth without development." The Chinese internet gives a new meaning to "involution": life characterized by competitiveness involving high internal friction and low innovation. 
The popularity of "involution" has drawn the attention of the academic community to a similar phenomenon in current academic research. The increasing investment in research has been paradoxically accompanied by increasingly mediocre academic production. High-intensity pressure induced by employment methods such as "quantitative assessment," "project-based survival," and "promotion or leave" have propelled repetitive articles and even endless plagiarism. This has had negative impacts on the academic environment. Increasing academic integrity and overcoming the impasse of academic "involution" not only requires institutional support from scientific evaluation and assessment but also depends on the location and self-reflection of scholars.

\section{Representative Publications}

Feng Haochen 馮晧辰. “Involution: How an Academic Term Gained Resonance with Examinees, Corporate Slaves, and the Times 內卷化: 一個學術名詞如何贏得考 生、社畜和時代的共鳴.” Jiemian 界面新聞, September 28, 2020.

He Xuefeng 賀雪峰. “Heeding the 'Involution' in Social Science Research 注意社科研 究“內卷化”傾向.” Global Times 環球網, August 26, 2020.

Huang, Philip C. C. 黄宗智. “When Involution Sweeps China? The Concept of 'Involution' and the Development of 'De-Involution' 當“內卷'席捲中國? 黃宗智 回應“內卷化概念與“去內卷化'發展." Yalipub (WeChat official account) 雅理讀書, October 19, 2020.

Li Xian 李弦 and Wu Shan 吳姗. “Understanding and Cracking 'Involution” “內卷化效 應的理解與破解”. Last modified December 14, 2020. http://www.cssn.cn/sxzzjypd/ sxzzjypd_bwsf/202012/t20201214_5231952.shtml.

Wang Qianni 王芉霓. “Archaeologist Xiang Biao on Involution: A Form of Competition That Allows Neither Failure nor Exit 人類學家項瓶談內卷: 一種不允許失敗和退 出的競爭.” The Paper 澎湃新聞, October 22, 2020.

Xu Jingjing 徐菁菁 and Guo Zijie 郭子介. “GPA Is King: The Prisoner's Dilemma of Young People at Chinese Universities 績點為王: 中國頂尖高校年輕人的囚徒困 境." Sanlian Life Weekly 三聯生活週刊, September 19, 2020.

Zhu Wenhui 朱文輝. "The Involution of Academic Governance: Its Connotation, Mechanism, and Solution 學術治理的內卷化: 內涵表徵、生成機理與破解之道." Journal of Higher Education 高等教育研究, no. 6 (2020). 


\section{Differences in Prevention and Control Models between China and the West Stimulated Cultural Contemplation as the covid Pandemic Accelerated "a Tremendous Change Unseen in a Century"}

In the face of the covid pandemic, the most serious public health emergency since the 1918 influenza pandemic, China and the West have demonstrated completely heterogeneous prevention and control models. The Chinese government and society mobilized quickly and took the lead in controlling the pandemic by virtue of strong dispatch capabilities, strict management, and rigorous control mechanisms. Western countries were less willing to mandate effective nonmedical prevention and control, which caused the pandemic to continue spreading. The differences in management models have prompted the academic community to compare the Chinese and Western models from the perspective of institutionalism and its cultural roots.

Theorists argue that China's rapid and successful handling of the pandemic showcases the advantage of China's governance system. This advantage is inseparable from the cultural and psychological roots in Confucianism. Although such Chinese cultural ideas that "everyone in the world is related" and "the community is greater than individuals" have drawbacks, they prove vital when dealing with major public emergencies. In comparison, the pandemic went out of control in the West as a result of liberalism, which prioritizes the value of individual rights. The covid pandemic has highlighted cultural differences and consequences. Developing a deep dialogue between Chinese and Western cultures from a constructive perspective to jointly cope with the world's "tremendous change unseen in a century" calls for urgent contemplation by scholars in China and overseas.

\section{Representative Publications}

He Huaihong 何懷宏 et al. "Anti-Epidemic and Modernization of National Governance in a Mobile and High-Risk Society: From the Perspective of Methodology 大流動、 高風險社會的抗疫與國家治理現代化: 方法論的視角." Exploration and Free Views 探索與爭鳴, no. 4 (2020).

Research Group on the Prevention and Control of the Covid-19 Epidemic at the National Institute of Development Strategy at Wuhan University 武漢大學國家 發展戰略研究院新冠病毒疫情防控研究課題組. “Research on China's Experience in Fighting the COVID-19 Epidemic 抗擊新冠病毒疫情的中國經驗.” Study and Practice 學習與實踐, no. 4 (2020). 
Shan Chao 單超. “China's Anti-Epidemic Campaign Promotes the Building of a Community with a Shared Future for Mankind: On the Book Launch of The International Contribution and Global Significance of China's Anti-Epidemic Campaign: China's Anti-Epidemic Campaign in the Eyes of Foreigners and a Review of the International Symposium of Anti-COVID-19 and Building a Community with a Shared Future for Mankind 中國抗疫推動構建人類命運共同體 - 〈中國戰‘疫”的國際貢獻和世界意 義 - 國外人士看中國抗疫 $>$ 新書發布會暨抗擊新冠肺炎疫情與構建人類命運共同 體國際研討會'綜述." Studies on Marxism 馬克思主義研究, no. 8 (2020).

Tang Huangfeng 唐皇鳳 and Huang Xiaoshan 黃小珊. “Party's Governing Capability for the Prevention and Control of COVID-19 新冠肺炎疫情防控彰顯政黨能力.” Exploration and Free Views 探索與爭鳴, no. 4 (2020).

Wang Mingke 王明珂. "Witch-Hunting Crisis: Humanistic Reflections on COVID-19 獵巫危機: 對新冠肺炎的人文省思.” Journal of the South-Central University for Nationalities 中南民族大學學報, no. 3 (2020).

Zhao Dingxin 趙鼎新. “COVID-19 and Chinese Reform 新冠疫情與中國改革.” Beijing Cultural Review 文化縱橫, no. 4 (2020).

Zhu Andong 朱安東 and Sun Jiemin 孫潔民. “COVID-19, Neoliberalism, and the Future of Capitalism 新冠病毒、新自由主義與資本主義的未來.” Marxism \& Reality 馬克 思主義與現實, no. 4 (2020).

Zou Shipeng 鄒詩鵬. “The New Coronavirus Disease Abuse and Prevention under the Civilization Test 文明考驗下的新冠疫情及防控.” Academia Bimestris 學海, no. 3 (2020).

\section{The Evaluation of Qin Shi Huang and the Qin System Made Waves Again amid Controversy over the Tv Series "Qin Dynasty Epic"}

In December 2020, CCTV broadcast the historical drama "Qin Dynasty Epic." As the story progressed, the initial high ratings fell, with polarizing opinions. In addition to distortions in historical details, the drama attempted to subvert the general perception of the Qin, in which "severe policies are fiercer than tigers" and "people are bitterly suffering Qin for a long time." The excessive embellishment of Qin Shi Huang's 秦始皇 [r. 246-210 BCE] victory aroused indignation by some viewers. It once again sparked discussion about the merits and demerits of the Qin dynasty [221-206 BCE] and Qin Shi Huang.

As the first "unifying" dynasty in Chinese history, the Qin dynasty established the system of counties and emperors, which formed the foundational structure of ancient Chinese states. For thousands of years, the historical significance of the Qin system and its underlying legalism have been a sensitive topic to discuss and explain. Intensive research driven by bamboo slips newly 
found in recent years has deepened our understanding of the political system, government events, and everyday life in the Qin dynasty. Nevertheless, evaluation of the Qin system raises disagreement. Some believe that the Qin system cannot be understood simply as an autocratic state with imperial power, as the way it worked was rather complicated; others continue to criticize the violence of the Qin by pointing to the excessive taxes levied. The evaluation of the Qin system is expected to remain controversial.

\section{Representative Publications}

Hou Xudong 侯旭東. “The Qin-Han Era Laid the Foundation for China for 2,ooo Years 秦漢時代奠基中華二千年.” China Business Journal 中國經營報, December 28, 2020. Jiang Dengfeng 姜登峰. “The End of the Qin Dynasty An Analysis of the Unbearable Responsibility of Legalist Thought 秦亡 - 法家思想不可承受之責的探析.” Journal of the Chinese University of Political Science and Law 中國政法大學學報, no. 4(2019). Liu Sanjie 劉三解. Qin Bricks: The Rise and Fall of the Qin Empire 秦磚: 大秦帝國興亡 啓示錄. Beijing: Beijing United, 2020 .

Song Jie 宋潔. “A New Explanation of 'Draw up Three Chapters of Law' “約法三章'新證 兼證漢承秦制”之開端” Wen shi 文史, no. 4 (2019).

Wang Zijin 王子今. “Archaeology of the Mausoleum of the First Qin Emperor and a New Conception of the Historical Significance of the Unification of the Qin 秦始皇 陵考古與秦統一歷史意義的新認識.” Qin-Han Studies 秦漢研究, 2020.

Wang Zijin 王子今. “On the 'Violence of the Qin State': Using the Historical Public Opinion on the Unification of Qin State as the Object '秦暴'評議: 以秦兼羊天下的 歷史興論爲對象." Journal of Chongqing Normal University 重慶師範大學學報, no. 4 (2020).

Xin Deyong 辛德勇. The Life and Death of Qin Shi Huang 生死秦始皇. Beijing: Zhonghua Book Company, 2019.

\section{Translated by Zhang Yin}

